\title{
НАПРЯМКИ УДОСКОНАЛЕННЯ НАУКОВО-МЕТОДИЧНОГО ЗАБЕЗПЕЧЕННЯ КРИМІНОЛОГІЧНӦ̈ ДІЯЛЬНОСТІ СУДОВО - ЕКСПЕРТНИХ УСТАНОВ УКРАЇНИ
}

\author{
ФІЛІЕНКО Наталія Свгенівна - кандидат юридичних наук, доцент, доцент \\ кафедри права Національного аерокосмічного університету ім. М. Є. Жуковського \\ «Харківський авіаційний інститут»
}

DOI 10.32782/LAW.2020.2.18

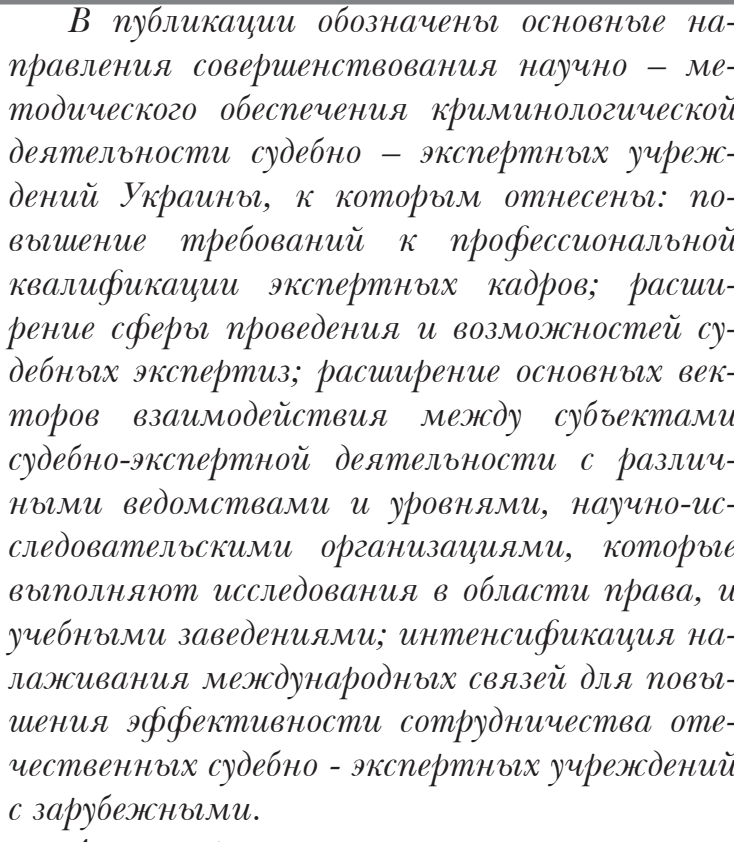

Акцентировано внимание на том, что научное обеспечение криминологической деятельности судебно - экспертньхх учреждений Украинъ является одним из приоритетнъих направлений обеспечения их деятельности. Отмечено? что каждое государственное спеииализированное уиреждение, осуществляющее судебно-экспертную деятельность в Украине, одновременно является и научным центром, который проводит научнъие разработки в области теории судебной экспертологии, в том иисле те, ито касаются внедрения в практику новъгх методик экспертнъхх исследований.

Подведен итог относительного того, что глубиннъе научнъе исследования проблемных аспектов экспертной практики, использование новейших наукоемких технологий при разработке методик проведения судебньих экспертиз являются залогом высокой вббективности криминологической деятельности судебно экспертнъх уиреждений Украинъ и минимизачии количества экспертньх ошибок.

Ключевъие слова: научное обеспечение, методическое обеспечение, направления усовершенствования, экспертная деятельность, международное сотрудничество, взаимодействие, сотрудничество.

\section{Постановка проблеми}

Рівень розвитку науки і техніки є визначальним чинником прогресу суспільства, підвищення добробуту громадян, їх духовного та інтелектуального зростання. Цим зумовлена необхідність пріоритетної державної підтримки розвитку науки як джерела економічного зростання i невід'ємної складової національної культури та освіти, створення умов для реалізації інтелектуального потенціалу громадян у сфері наукової і науково-технічної діяльності, забезпечення використання досягнень вітчизняної та світової науки і техніки для задоволення соціальних, економічних, культурних та інших потреб [1].

Наукове забезпечення є невід'ємним у практичній діяльності судово - експертних установ, адже розробка експертних методик, подальше теоретичне осмислення та практичне застосування отриманих 
результатів базується на досягненнях науки і техніки.

Якісне наукове забезпечення кримінологічної діяльності судово - експертних установ України є підгрунтям успішної роботи як окремих експертів, так і експертних установ, а використання накопичених знань, спеціальних у тому числі, в комплексі з іншими елементами системи забезпечення судово - експертної діяльності в Україні є основою її ефективності.

\section{Аналіз останніх досліджень і публікацій}

Питання науково - методичного забезпечення, як одного 3 напрямків кримінологічного забезпечення діяльності судовоекспертних установ України, не позбавлене наукового інтересу і досить широко висвітлене в наукових працях провідних українських та зарубіжних науковців спеціалістів у галузі судової експертологї̈, зокрема це: Т.В. Авер'янова, А.Ю. Ароцкер, В.Д. Арсеньєв, В.Д. Басай, В.В. Бірюков, А.І. Вінберг, О.О. Ейсман, О.М. Зінін, А.В. Іщенко, Н.I. Клименко, М.В. Костицький, В.К. Аисиченко, О.М. Аитвинов, Г.М. Надгорний, І.В. Пиріг, М.Я. Сегай, Е. Б. Сімакова-Сфремян, І.Я. Фрідман, М.Г.Щербаковський та ін.

Метою даної публікації є окреслення основних напрямків удосконалення науково - методичного забезпечення кримінологічної діяльності судово - експертних установ України.

\section{Виклад основного матеріалу}

Досвід проведення успішних модернізацій у європейських країнах та сучасна демократична практика засвідчують важливість залучення до процесу формування державної політики науково - експертного середовища, що дає можливість грунтовного, незаангажованого аналізу всіх підходів і пропозицій щодо змісту, напрямів формування програм розвитку країни та отримання потужного наукового ресурсу на різних рівнях їх розробки, публічного обговорення і здійснення [2, с. 202-203]. В повній мірі це стосується судово-експерт- них установ України, які, з одного боку, є суб'єктами наукового забезпечення кримінального судочинства, а з іншого, експертні дослідження, які проводяться в цих установах, повинні спиратись на міцну наукову основу, бути науково обгрунтованими і достовірними.

Законодавчу основу здійснення наукової діяльності судово-експертних установ України складають Закони та підзаконні нормативно - правові акти, в яких закладено основи, базис функціонування цих установ. Ними врегульовано питання щодо організації та проведення наукових досліджень у галузі судової експертології, визначено основні форми впровадження та особливості перевірки достовірності отриманих результатів нових методик.

Так, законом України «Про судову експертизу» визначено правові, організаційні і фінансові основи судово-експертної діяльності з метою забезпечення правосуддя України незалежною, кваліфікованою і об'єктивною експертизою, орієнтованою на максимальне використання досягнень науки і техніки. При цьому судова експертиза - це дослідження на основі спеціальних знань у галузі науки, техніки, мистецтва, ремесла тощо об'єктів, явищ і процесів $з$ метою надання висновку з питань, що є або будуть предметом судового розгляду [3]. Тобто вже зі змісту основних положень розглядуваного Закону чітко простежується виняткова роль науки в діяльності судово - експертних установ України.

У той же час, судова експертиза, як процес пізнання, включає в себе серед загальнонаукових методів основні функції: гносеологічна, процесуальна, організаційна, етимологічна. Такий процес пізнання науки про судову експертизу є віддзеркаленням у наукових принципах, поняттях і закономірностях свого об'єкта - судовоекспертної діяльності, яке визначає одну 3 організаційно-складових форм - науковометодичне забезпечення, що, у свою чергу, сприяє збільшенню обсягу експертної роботи, значній активізації наукових досліджень з метою подальшого розроблення методологічних засад для поглиблення пізнання предмету судової експертології 


\section{Кримінальне право, кримінальний процес та криміналістика}

і підготовки кадрів вищої кваліфікації та створення наукової школи однодумців[4, с. 17].

Питання значущості, актуальності, важливості і затребуваності судово - експертної діяльності безсумнівне, проте існує ряд моментів, які гальмують їі розвиток. А він є невпинним, цьому сприяють глобалізаційні процеси, науково-технічний процес, що надає можливості для розвитку і вдосконалення як матеріального світу, так і людської свідомості. Крім того, ці процеси обумовлені діалектичними законами прогресивного розвитку суспільства. Експертна діяльність, що досліджує саме ці закономірності навколишнього середовища, не може стояти осторонь, повинна постійно удосконалюватись і розвиватись. Основними напрямками удосконалення науково - методичного забезпечення експертної діяльності в Україні 6 :

Підвищення вимог до професійної квалібікаиіӥ експертних кадрів. Динамічний розвиток судово-експертної діяльності в Україні, впровадження в практику судово-експертних установ Міністерства юстиції нових технологій, а також зростання вимог до якості проведення судових експертиз визначають актуальність завдань щодо вдосконалення підготовки наукових кадрів вищої кваліфікації для потреб судово-експертної діяльності. Нині питання підготовки фахівців судово-експертних установ Міністерства юстиції України та фахівців, які не є працівниками цих установ, а також підготовки наукових кадрів вищої кваліфікації є одним із пріоритетних при вирішенні завдань реформування судової експертизи, спрямованих на їі подальший розвиток і підвищення якості експертних досліджень [5, с. 281].

Специфічною ознакою діяльності судово-експертних установ є поєднання науково-дослідницької, науково-методичної та науково-виробничої діяльності, що здійснюеться, головним чином, одними і тими ж особами. Питання професійної підготовки у галузі наукової діяльності за таких обставин є невід'ємним від питань загальної професійної підготовки експертів, які $\epsilon$, по суті, науково-практичними кадрами [6,c. 136].

Відповідно до статті 10 ЗУ «Про судову експертизу», судовими експертами державних спеціалізованих установ можуть бути фахівці, які мають відповідну вищу освіту, освітньо-кваліфікаційний рівень не нижче спеціаліста, пройшли відповідну підготовку та отримали кваліфікацію судового експерта з певної спеціальності.

До проведення судових експертиз (обстежень і досліджень), крім тих, що проводяться виключно державними спеціалізованими установами, можуть залучатися також судові експерти, які не 6 працівниками цих установ, за умови, що вони мають відповідну вищу освіту, освітньокваліфікаційний рівень не нижче спеціаліста, пройшли відповідну підготовку в державних спеціалізованих установах Міністерства юстиції України, атестовані та отримали кваліфікацію судового експерта з певної спеціальності у порядку, передбаченому цим Законом [3].

Тобто, в принципі законодавчо закріпленим є те, що судовим експертом апріорі не може бути особа без відповідної освіти, кваліфікаційного рівня, наявності спеціальних знань, вмінь і навичок.

Однак, вчені вказують на відсутність програм магістерської підготовки в галузі судової експертизи, у зв'язку з чим видається доцільним удосконалення системи підготовки експертних кадрів на кафедрах (в інститутах) судово-експертної діяльності у державних вищих навчальних закладах, що мають відповідну наукову базу та в належний спосіб підготовлений професорсько-викладацький склад за напрямами судово-експертної діяльності. Навчальний процес має бути орієнтований на випуск фахівців певних профілів (спеціальностей), а набуті ними знання під час навчання повинні відповідати встановленим для судових експертів відповідних спеціальностей ступеню, глибині, характеру засвоєння і подальшій реалізації [7, с. 232].

Сьогоденний стрімкий розвиток усіх сфер суспільного життя, науково-технічний прогрес кидає виклики i судовим експертам, постійно розширюючи коло 
розв’язуваних задач, у зв’язку з чим перед експертами систематично постають нові питання, практики вирішення яких немає, а їх розв’язання потребує високого інтелектуального потенціалу.

Найбільш ефективною вбачається розробка науково-методичних матеріалів самими судово-експертними установами. Зумовлено це тим, що експерти краще за інших знають свої потреби в методиках, можливості технічного забезпечення тощо. До позитивних рис також можна віднести широкі можливості апробації та накопичення статистичних даних. Разом 3 тим тут також є негативні моменти. Науковою роботою експертам часто доводиться займатися паралельно зі своєю основною роботою - виконанням експертиз. Якщо врахувати значну завантаженість експертів (в окремих випадках експертизи розписані на декілька років вперед), можна зрозуміти, що для якісної наукової роботи елементарно не залишається часу.

Основною роботою експерта є виконання судових експертиз. Відповідно, підготовка науково-методичних матеріалів залишається, на превеликий жаль, не пріоритетним завданням, тому кількість і якість такої методичної роботи не завжди відповідає нагальним потребам [8].

Раціональне використання і розвиток потенціалу судових експертів як науковців сприятиме виробленню єдиного підходу до методики проведення експертних досліджень, якісно новому рівню сертифікації, апробації та послідуючої реалізації методичного забезпечення.

Систематичне підвищення професійного рівня вченого, експерта-професіонала $\varepsilon$ запорукою проведення експертиз на високому рівні з мінімалізацією кількості експертних помилок та забезпеченням високого рівня достовірності результатів експертиз.

Розширення сбери проведення та можливостей судових експертиз. Наукові дослідження, пов'язані зі створенням нових методик проведення судових експертиз (планування, безпосередньо проведення наукових робіт, апробація і впровадження їх результатів в експертну практику), є вкрай актуальною задачею для судово експертних установ України. Вона повинна вирішуватися системно та масштабно, грунтуватися на визначенні концептуальних напрямків, широкому використанні ресурсного, нормативно - правового і інтелектуального потенціалу, чіткому плануванні діяльності з урахуванням пріоритетів та особливостей досліджуваного явища.

Актуальною на сьогодні $\epsilon$ розробка нових високотехнологічних методик експертних досліджень у зв'язку 3 появою нових об'єктів та інтенсивним розвитком вже існуючих (перш за все пов'язаних із розвитком біотехнологій, генної інженерії, молекулярної генетики, сучасної фармацевтики, комп'ютерних систем і технологій і т. ін.), що потребує проведення грунтовних наукових досліджень.

Безпосередньо пов'язаним із вказаним напрямком є фінансове забезпечення наукових досліджень. На рівні з необхідністю розвитку наукового потенціалу слід вказати на значущість інвестицій у наукові дослідження, адже часто ефективність реалізації інноваційних проєктів напряму залежить від їх фінансування, яким обумовлюється матеріально - технічна база. 3більшення рівня фінансування наукових досліджень, у свою чергу, сприятиме досягненню значно кращих результатів, які в матеріальному сенсі перевищать витрати, і ця взаємообумовленість є основою прогресу.

Перспективи розвитку судової експертології залежать від ефективності провадження державної політики щодо належного забезпечення судово-експертної діяльності в Україні. Як багато інших сфер державного регулювання, цей напрям також потребує періодичної верифікації та реформування 3 урахуванням міжнародних стандартів використання спеціальних знань у кримінальному провадженні. Створення необхідних умов для діяльності судового експерта вважається однією із гарантій незалежності судового експерта та правильності його висновку [9, с. 164].

Взаємодія між суб’єктами судово-експертної діяльності за різними відомствами та рівнями, науково-дослідними організаціями, 


\section{Кримінальне право, кримінальний процес та криміналістика}

що виконують дослідження в галузі права, та навчальними закладами. Судово-експертну діяльність здійснюють державні спеціалізовані установи, їх територіальні філії, експертні установи комунальної форми власності, а також судові експерти, які не $є$ працівниками зазначених установ, та інші фахівці (експерти) 3 відповідних галузей знань у порядку та на умовах, визначених Законом України «Про судову експерти3y».

Так науковці 3 цього приводу вказують, що на сьогодні особливістю судовоекспертної діяльності є відсутність нормативного, організаційного, методичного та інформаційного регулювання іï окремих сфер на всіх рівнях здійснення. Спроба державних спеціалізованих установ на відомчому рівні вирішити певні проблемні питання призводить до розрізненості науково-дослідної роботи та виникнення конкуренції між суб'єктами судово-експертної діяльності не лише на грунті наукових розробок, а й при здійсненні судово-експертної практики [10, с. 3].

Перш за все потребує врегулювання процес взаємодії між державними та недержавними експертами. Так, наприклад, судові експерти, які не $\epsilon$ працівниками державних спеціалізованих установ, можуть проводити багато видів експертиз, що не включені в перелік судових експертиз, які проводяться в державних спеціалізованих установах. Тож з метою обміну досвідом, знаннями і практичними навичками у вирішенні окремих питань доцільним вбачається створення спільних робочих груп з розробки методик судовоекспертних досліджень на основі постійної взаємодії і творчого співробітництва.

Ефективною вбачається i взаємодія судово - експертних установ 3 науководослідними організаціями, що виконують дослідження в галузі права, та навчальними закладами. Найбільш тісним 6 взаємозв' язок судово - експертних установ України з Національною академією правових наук України, Науково-дослідним інститутом вивчення проблем злочинності імені академіка В.В. Сташиса, вищими навчальними закладами системи МВС Укра- їни, закладами вищої освіти, які здійснюють фундаментальну підготовку майбутніх судових експертів.

Основними векторами такої взаємодії є наступні: спільний аналіз актуальної тематики науково-дослідних та дослідноконструкторських робіт, проведення грунтовних наукових досліджень 3 подальшим впровадженням результатів у практичну діяльність органів кримінального судочинства, обмін науковою інформацією (методичними, науковими довідковими матеріалами, статистичними даними, та їх узагальненнями) досвідом роботи в різних напрямках, що 6 необхідною складовою формування і реалізації науково - обгрунтованої і ефективної політики держави щодо протидії злочинності.

Необхідним у цьому напрямку є оприлюднення результатів наукових досліджень шляхом організації та проведення міжвідомчих науково-методичних конференцій, семінарів, нарад, круглих столів, семінарів, науково-практичних конференцій, засідань, дебатних клубів, проведення бінарних занять з актуальних проблем судової експертизи.

Крім того, дотичними є такі напрямки спільної діяльності, як написання та наступний захист дисертаційних досліджень, видання монографій, підручників, навчальних та навчально-методичних посібників, читання курсів лекцій з актуальних питань експертного забезпечення досудового розслідування.

Окрім законодавчо визначених та врегульованих форм та методів взаємодії між суб'єктами судово - експертної діяльності за різними відомствами та рівнями, існують інші форми взаємодії, що вироблені практикою. Адже саме практика є мірилом доцільності та показником ефективності такого співробітництва, вона як лакмусовий папір відображає нагальні соціальні потреби та пропонує шляхи їх вирішення. Безумовно, така взаємодія може носити рекомендаційний або консультативний характер (мова може йти про взаємодію зі спеціалістами окремих напрямків життєдіяльності суспільства, це може бути промислова, фінансова, підприємницька, 
культурно- просвітницька або будь-яка інша сфера).

Міжнародна взаємодія та співпраия. Імплементація європейських стандартів у діяльність експертних установ України є вкрай перспективним напрямком розвитку судово-експертної діяльності. Уніфікація методик вітчизняних експертних досліджень 3 методиками європейських країн, які були апробовані на міжнародному рівні, в разі реальної можливості їх якісної адаптації до українського законодавства забезпечить розширення міжнародної співпраці в галузі наукових досліджень на етапі євроінтеграційних процесів у нашій державі.

Найбільш великою та розвинутою $\epsilon$ Европейська мережа судово-експертних установ The European Network of Forensic Science Institutes - ENFSI. Вона заснована у 1995 році для покращення обміну інформацією у сфері судової експертизи, а також підвищення якості судово-експертної діяльності у світі. ENFSI була визнана Европейською комісією як одна 3 провідних організацій у галузі судової експертизи. Це найбільша у світі об'єднана організація судово-експертних установ, що отримала міжнародне визнання [11].

Вступ до ENFSI якомога більшого числа судово-експертних установ України(окрім тих, які вже є постійними членами) відкриває «нові горизонти» плідної співпраці в означеному напрямку. Адже, національна судова експертиза не може існувати ізольовано, тобто в межах окремої держави. Вона не виконуватиме активно свої функції забезпечення правоохоронної діяльності поза інтеграцією з міжнародною спільнотою [12, с. 166].

Крім того перспективною в напрямку міжнародного співробітництва вбачається інтенсифікація проведення міжнародних стажувань працівників судово-експертних установ України, розробка на основі отриманих ними знань, вмінь та навичок ефективних механізмів реалізації спільних дослідницьких програм, наукових проєктів у діяльність судово-експертних установ України.
Однак слід зауважити, що укріплення міжнародного співробітництва в області судової експертизи потребує розробки та послідуючого використання науково обгрунтованих механізмів імплементації відповідної законодавчої бази, адже вона повинна відповідати $з$ одного боку національним принципам, а 3 іншого - міжнародним правовим і професійним стандартам.

Резюмуючи, слід вказати, що кримінологічна діяльність судово - експертних установ України повинна бути якісно науково-методично забезпеченою. Це положення є аксіоматичним. Адже постійно зростаючі потреби кримінального судочинства обумовлюють перехід на новий рівень судово - експертних досліджень 3 урахуванням сучасних вимог. Виняткова роль у цих трансформаціях належить науці, яка завжди іде попереду практики, i властивими їй методами здатна «передбачити» розвиток певних процесів в майбутньому. Від якості науково - методичного забезпечення експертної діяльності напряму залежить кількість експертних помилок, які допускаються судовими експертами, у зв'язку з чим підвищення наукового рівня як методик проведення судових експертиз, так і кримінального судочинства в цілому можливе завдяки поєднанню високого інтелектуального потенціалу академічної науки 3 практичним експертним досвідом.

Глибинні наукові дослідження проблемних аспектів експертної практики, використання найновіших наукоємних технологій при проведенні судових експертиз є запорукою підвищення ефективності кримінологічної діяльності судово експертних установ України.

\section{Література}

1. Про наукову i науково-технічну діяльність: Закон України від 13 грудня 1991 року № 1977-XII / Верховна Рада України. URL: http:// https://zakon.rada. gov.ua/laws/show/848-19\#Text (дата звернення 10.09.2020).

2. Логунова М., Пшеничнюк О. Наукове забезпечення процесу формування 


\section{Кримінальне право, кримінальний процес та криміналістика}

й реалізації державної політики в умовах модернізації українського суспільства. Вісник Національної академії державного управління. 2012. №4. С. 201-210.

3. Про судову експертизу : Закон України від 25 лютого 1994 р. № 4038XII / Верховна Рада України. URL: http:// zakon4.rada.gov.ua/laws/show/4038-12 (дата звернення 10.09.2020).

4. Антонова М.М. Вплив науково-методичного забезпечення щодо проведення судових експертиз в Україні // Судово-експертна діяльність: сучасний стан та перспективи розвитку: збірник матеріалів круглого столу (23 квітня 2015 року). Київ: Навчально-науковий інститут підготовки фахівців для експертно-криміналістичних підрозділів Національної академії внутрішніх справ. 2015. С. 16-20.

5. Гаспарян С.Г. Шляхи підвищення якості підготовки кадрів для судовоекспертних установ міністерства юстиції України. Теорія та практика судової експертизи і криміналістики. 2018. Вип.18. С.281287.

6. Репешко П.І. До питання кадрового забезпечення державних судово-експертних установ. Наукові праиі Чорноморського державного університету імені Петра Могили. Сер. Політологія. 2010. Т. 131, Вип. 118. С. 136-139.

7. Бараняк В.М. Проблеми підготовки судових експертів у вищих навчальних закладах України. Вісник Наџіонального університету «Аввівсъка політехніка». Юридичні науки. 2014. № 801. С. 229-233.

8. Надіжко М.M. Деякі питання науково-методичного забезпечення судовоекспертної діяльності в системі СБ України (на прикладі комп'ютерно-технічних досліджень). URL: http://academy.ssu.gov. ua/ua/page/page_1581425700.htm (дата звернення 10.09.2020).

9. Дуфенюк О. М. Забезпечення судово-експертної діяльності у кримінальному провадженні: системна парадигма Вісник Аьвівсъкого торговельно-економічного універcumemy. Юридичні науки. 2019. Вип. 8.C. 164-173.

10. Антонюк П.Е. Вітальне слово до початку роботи круглого столу // Судо- во-експертна діяльність: сучасний стан та перспективи розвитку: збірник матеріалів круглого столу Київ (23 квіт.2015 р.). Навчально-науковий інститут підготовки фахівців для експертно-криміналістичних підрозділів Національної академії внутрішніх справ. 2015. С. 2-3.

11. Харківський НДІ судових експертиз ім. Засл. проф. М.С. Бокаріуса. URL: https://www.hniise.gov.ua/14280-pochatokzasdannya-vropeis k o-merezh-sudovoekspertnix-ustanov-enfsi.html (дата звернення 10.09.2020).

12. Клименко Н. І. Міжнародне значення судово-експертної діяльності // Судово-експертна діяльність: сучасний стан та перспективи розвитку : збірник матеріалів круглого столу (23 квітня 2015 року). Київ: Навчальнонауковий інститут підготовки фахівців для експертно-криміналістичних підрозділів Національної академії внутрішніх справ,. 2015. С. 165-168.

\section{DIRECTIONS FOR IMPROVING SCI- ENTIFIC AND METHODOLOGICAL PROVISION OF CRIMINOLOGICAL AC- TIVITY OF FORENSIC INSTITUTIONS OF UKRAINE}

The author of the publication has outlined the main directions for improving scientific and methodological provision of criminological activity of forensic institutions of Ukraine, which include: strengthening the requirements for professional qualification of expert staff; expanding the scope and possibilities of forensic examinations; expanding the range of main vectors of interaction between the subjects of forensic activity at different departments and levels, research organizations conducting research in the field of law, and educational institutions; intensification of international relations to increase the effectiveness of cooperation of national forensic institutions with foreign ones.

It has been emphasized that the scientific provision of criminological activities of forensic institutions of Ukraine is one of the priority areas of ensuring their activities. It has been noted that each state specialized institution that carries out forensic activities 


\begin{tabular}{|c|}
\hline 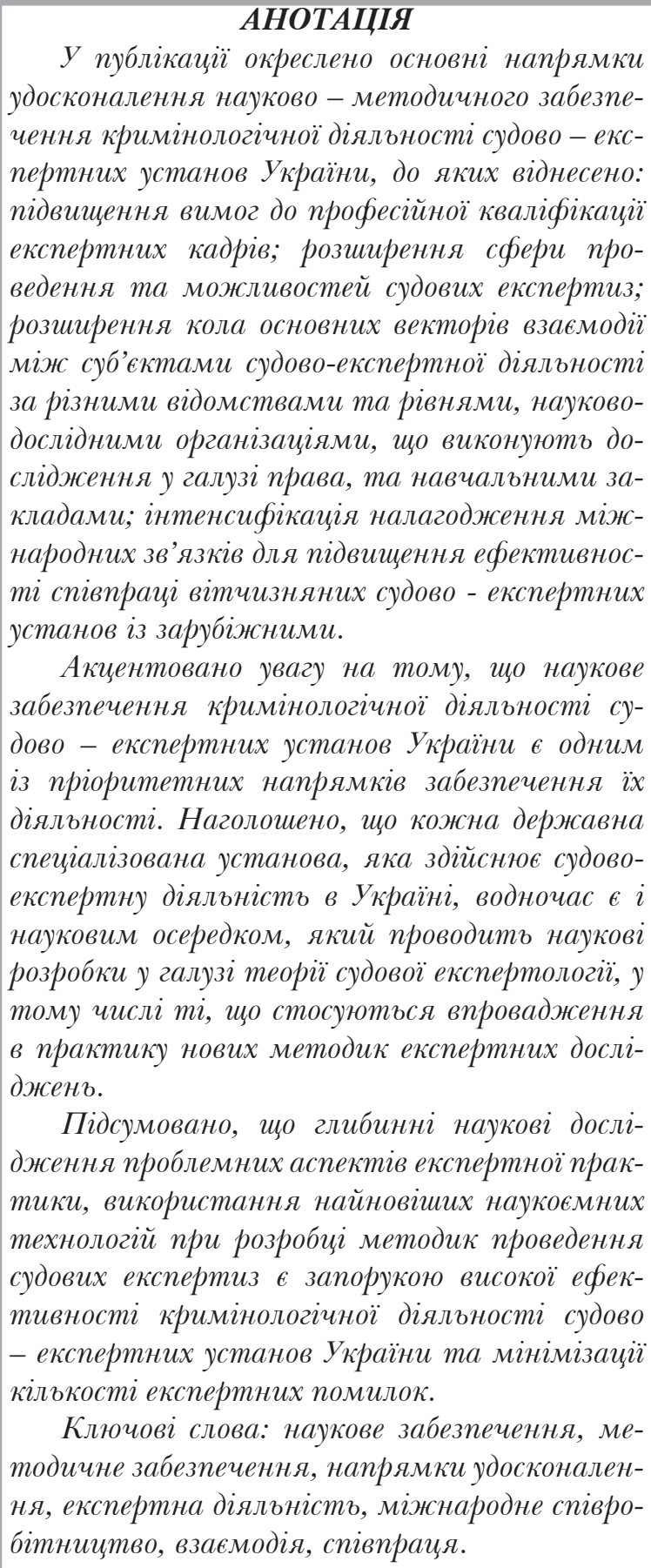 \\
\hline
\end{tabular}

in Ukraine is also a research center that conducts research in the field of theory of forensic expertise, including those related to the implementation of new methods of expert research into practice.

It has been concluded that in-depth scientific research of problematic aspects of expert practice, use of the latest scientific technologies in the development of methods for carrying out forensic examinations is a guarantee of high efficiency of criminological activity of forensic institutions of Ukraine and minimization of the number of expert drawbacks.

Key words: scientific provision, methodical provision, directions of improvement, expert activity, international cooperation, interaction, cooperation. 